Journal of Social Sciences 3 (4): 185-189, 2007

ISSN 1549-3652

(C) 2007 Science Publications

\title{
Auditors Compliance with International Standards on Auditing (ISAs): Evidence form Jordan
}

\author{
Obaidat, Ahmad N \\ Department of Business Economics, Tafila Technical University, Tafila, Jordan
}

\begin{abstract}
The continuous new amendments of the International Standards on Auditing (ISAs) in the beginning of 2007 formed a pressure on auditors to follow up and comply with them. The present study attempted to examine to what extent auditors complied with ISA according to the last pronouncement by the International Auditing and Assurance Standard Board (IAASB). Data was collected through a questionnaire administered to a random sample of external auditors in Jordan. The study revealed that Jordanian auditors complied with all auditing standards with some variance in the degree of compliance among them. The results indicated that further measures and steps could be taken to improve the ISA compliance.
\end{abstract}

Keywords: Auditors, International Standards on Auditing (ISAs), International Auditing and Assurance Standard Board (IAASB)

\section{INTRODUCTION}

If you are an auditor, you need to understand the ISA and be aware of the new amendments and you need to get up to speed to ensure that they are addressed in your engagements as the complicated changes in business environment result in continuous and rapid amendments of the ISA, as they served as benchmark for high-quality auditing and gave the auditors good tools to cope with the increased and changing demand for audit services.

As a result of the lack of study in the field of auditors' compliance with ISA in Jordan, this study got its significance. Most of the studies in Jordan handled with individuals auditing standards. Only the report of the World Bank ${ }^{[1]}$ in 2004 discussed it and found out that there were considerable steps that had been taken to improve the audit profession in Jordan and to narrow the compliance gap in both accounting and auditing practice. So, this study came to cover this area to add more practical details to that report. And to draw a whole picture about ISA which is followed by Jordanian Auditor, so it will create new opportunities for future studies by underlining the standards that need more attention.

International Standards on Auditing (ISAs): The International Standards on Auditing (ISAs) were issued by the International Auditing and Assurance Standards Board (IAASB) of the International
Federation of Accountants (IFAC), which is a worldwide organization for accountancy profession, Founded in 1977 with 155 members and associates in 118 countries. IAASB Also develops the International Standards on Review Engagements, which deal with the audit and review of historical financial statements, the International Standards on Assurance Engagements, which deal with assurance engagements other than the audit or review of historical financial information, and related practice statements. They establish standards and provide guidance for auditors and other professional accountants, and provide guidance in specialized areas. In addition, the IAASB develops quality control standards for firms and engagement teams in the practice areas of audit, assurance and related services ${ }^{[2]}$.

The purpose of the International Standards on Auditing (ISA) is to establish standards and provide guidance on the objective and general principles governing an audit of financial statements.

In recent years there have been significant changes to international auditing standard-setting processes. These changes, reflected today in the standard-setting activities of the (IFAC), include greater direct public input, more rigorous and transparent processes and international public interest oversight. And according to the last pronouncements by (IAASB) in 2007, the International Standards on Auditing can be listed in table 1 .

Corresponding Author: $\quad$ Obaidat, Ahmad N., Department of Business Economics, Tafila Technical University, Tafila, Jordan, PO Box 179 Tafila 66110, Jordan, Tel: +962777448845 
Many of IFAC's member organizations have already adopted its (ISAs) - more than 70 bodies currently - and its independence standards, which are part of the IFAC Code of Ethics for Professional Accountants. Thus, the process of convergence is well under way. In addition, the adoption by the European Union of the 8th Directive on Company Law will likely result in an EU mandate for auditors to use IFAC's auditing standards in 2007, pursuant to an EU endorsement process, when conducting statutory audits that are already required for nearly all companies in the EU member states ${ }^{[3]}$.

A new survey ${ }^{[4]}$ shows that the changes deal principally with the planning of audits and involve auditors spending more time with clients and in many cases are likely to require extra involvement by the audit partner, and mean more work for auditors and higher fees for clients.

A new international study commissioned by the Board of the International Federation of Accountants (IFAC) and prepared by Peter Wong, a former member of the IFAC board identifies the challenges to adopting and implementing International Financial Reporting Standards (IFRS) and International Standards on Auditing (ISA). It recommends actions to be taken by all those in the financial reporting supply chain to achieve convergence to international standards. This study identifies six primary challenges to international convergence ${ }^{[5]}$ :

1. The need to develop standards that are capable of translation and to establish processes that facilitate high quality translations of the standard to more effectively accommodate the needs of non native English speakers

2. Complexity and structure of the standards

3. Frequency, volume and complexity of changes to the standards

4. Challenges for small and medium-sized companies and accounting firms

5. The potential knowledge shortfall among those responsible for implementing the standards

6. Lack of a universal understanding of the meaning of "international convergence".

Auditing in Jordan: The first auditing firm was established in Jordan in 1944; before that the auditing services were provided through auditing firms in Palestine. The professional codes were taken from British Companies Law, until the issuance of the Jordanian Companies Law 33/1962 ${ }^{[6]}$. Jordanian Association of Certified Public Accountants (JACPA) board was founded in 1988 (under Law 42/1987). A new Accountancy Profession Law 73/2003 was issued on June 16, 2003. Important features of the Accountancy Profession Law include the establishment of a "High Council for Accounting and

Table 1: International Standards on Auditing

No. General Category / Standard

GENERAL PRINCIPLES AND RESPONSIBILITIES

200 Objective and General Principles Governing an Audit of Financial Statements.

210 Terms of Audit Engagements.

220 Quality Control for Audits of Historical Financial Information.

230 Audit Documentation.

240 The Auditor's Responsibility to Consider Fraud in an Audit of Financial Statements.

250 Consideration of Laws and Regulations in an Audit of Financial Statements.

260 Communication of Audit Matters with Those Charged with Governance.

RISK ASSESSMENT AND RESPONSE TO ASSESSED RISKS

300 Planning an Audit of Financial Statements.

315 Understanding the Entity and Its Environment and Assessing the Risks of Material Misstatement.

320 Audit Materiality.

330 The Auditor's Procedures in Response to Assessed Risks.

402 Audit Considerations Relating to Entities Using Service Organizations.

AUDIT EVIDENCE

500 Audit Evidence.

501 Audit Evidence-Additional Considerations for Specific Items.

505 External Confirmations.

510 Initial Engagements-Opening Balances.

520 Analytical Procedures.

530 Audit Sampling and Other Means of Testing.

540 Audit of Accounting Estimates.

545 Auditing Fair Value Measurements and Disclosures. Related Parties.

550 Subsequent Events.

560 Going Concern.

570 Management Representations.

580

USING WORK OF OTHERS

600 Using the Work of Another Auditor.

610 Considering the Work of Internal Auditing.

620 Using the Work of an Expert.

AUDIT CONCLUSIONS AND REPORTING

700 The Independent Auditor's Report on a Complete Set of General Purpose Financial Statements.

701 Modifications to the Independent Auditor's Report.

710 Comparatives.

720 Other Information in Documents Containing Audited Financial Statements.

SPECIALIZED AREAS

800 The Independent Auditor's Report on Special Purpose Audit Engagements. 
Auditing" headed by the Minister of Industry and Trade, and the creation of an improved (JACPA).

The new Companies Law 22/1997 obliges all companies registered under the Companies Law to maintain sound accounting records and present annual audited financial statements in accordance with "internationally recognized accounting and auditing principles." Auditors are elected for one year with the possibility of renewal. The Accountancy Profession Law gives new powers to (JACPA), such as responsibility to draft its laws, disciplinary authority over its own members, and the right to inspect its members' working papers.

Many members of the Jordanian Associated for Certified Public Accountants (JACPA) reside outside Jordan. Members earn JACPA admission when they meet the educational requirements: (a) university degree with a major in accountancy, (b) diploma in accountancy, (c) a related university degree, not majoring in accountancy, but with accounting courses meeting the minimum threshold, and (d) membership in an acceptable foreign professional body. These requirements are in addition to passing the licensing examination administered by the licensing committee. This law determined the auditor rights and responsibilities, professional ethics, and stated that the auditors should comply with International Standards on Auditing issued by The International Auditing and Assurance Standards Board in conducting the audit engagement.

The World Bank report showed that the quality of some audits in Jordan was materially affected by management attitudes in client companies, and severe competition between audit firms. And it is observed that the quality of many audits is affected by management misconception about the value-added created by audit. Management attitude contributes to the low audit fees. Thus the degree of compliance with the applicable auditing standards varies between large and small firms.

\section{MATERIALS AND METHODS}

Study Hypotheses: This study is based on the following hypotheses:

Ho: Jordanian auditors do not comply with ISA.

HA: Jordanian auditors comply with ISA.

Study area: the study was conducted in Jordan in April 2007.
Study sample: the sample of the study consist of 40 of external auditor.

Data collection: in order to collect the data required, a survey questionnaire was developed and administered to a random sample of external auditors in Jordan but 29 replies were received.

The questionnaire contained the (ISAs) according to the last pronouncement by (ISAAB) in 2007, and with five scales reflecting the degree of compliance.

Statistical analysis: in order test the study hypotheses; one-sample T-test was used at (0.05) significant level. $\mathrm{T}$ was calculated through the following function:

$t=\frac{X-\mu}{S_{X}}$

Where,

$\bar{X}$ : is the sample mean.

$Q$ : is the population mean.

$S_{X}$

$X:$ is the standard error of the mean.

The Null hypothesis will be rejected if the calculated T is greater than 1.96 .

\section{RESULTS}

The statistical results for the one-sample t-test (table 2) showed that the calculated (T) for all standards are higher than (1.96), thus the null hypothesis is rejected and the alternative hypothesis is accepted. This means that Jordanian auditors comply with all auditing standards and they are following up the new changes and amendments in the ISA to ensure high-quality audit services. Also summary statistics (means or percentages) for the standards used in this study are presented in table 2; these means reflect the degree of compliance by auditors with auditing standards, the highest mean which is $90.34 \%$ that is the highest degree of compliance, and the lowest mean which is $70.34 \%$ that is the lowest degree of compliance. So, there is a variance in the degree of compliance among the standards. Ranking the standards according to the degree of compliance (mean) could be presented in table 3. Discussing the statistical results for all standards could be useless because of the possibility of distraction for the main idea and will be leaved for further researches. The focusing will be on the standards with the highest and lowest mean. Despite 
of the result that the Jordanian auditors comply with all standards, the difference between the standards with highest and lowest degree of compliance arise clearly. Is it difficult to comply with all standards at the same level? The special conditions and circumstances in Jordan could help in explaining this fact.

Auditing standard No. 500 (audit evidence) and No. 230 (audit documentations) showed a high degree of compliance, with $90.34 \%$ and $87.59 \%$ respectively, and we can consider it a normal result because Jordanian auditors, like most auditors, spend most of their time in planning for audit and accumulating evidence. Also standard No. 250 (consideration of laws and regulations in an audit of financial statements) showed a high degree of compliance, with $87.59 \%$, because Jordanian laws regulating the audit profession emphasize that the auditors should take into consideration all local laws in an audit of financial statements.

On the other hand, standard No. 600 (using the work of another auditor) and No. 800 (the independent auditor's report on special purpose audit engagements) showed a low degree of compliance, with $70.34 \%$ and $75.17 \%$ respectively. This could be attributed to the fact that in Jordan, there are a few cases where the auditor uses a work of another auditor or he/she is appointed to audit for special purposes. The common audit in Jordan is a usual or a complete audit to express an opinion on the fairness of financial statements.

The study also reveled to two important results and they need more attention: first, the Jordanian Accountancy Profession Law 73/2003 dictates that companies are required to hire a certified public accountant in any job related to accounting, but most CPAs prefer to work in CPA firm than to work as an internal auditor in other companies due to return reasons. So, most companies could not hire a CPA as an internal auditor with high cost, which weakens the reliability of internal auditing. So, standard No. 610 (considering the work of internal auditing) showed a low degree of compliance with $74.48 \%$. Second, because of the low fraud cases in Jordan, auditors did not properly consider standard No. 240 (the auditor's responsibility to consider fraud in an audit of financial statements) which showed a low degree of compliance with $73.79 \%$, so, this point needs more attention to avoid danger before it happens.

\section{CONCLUSION}

This study aimed at examining the degree of compliance of Jordanian auditors with ISA. According to statistical test results, the study null hypothesis was rejected which means that Jordanian auditors complied with all auditing standards, and this result was confirmed by the World Bank report. This result is due to strict conditions and requirements of Jordanian laws regulating the audit profession to be a certified public accountant as well as strict legal liabilities. So today the number of CPAs approximates 400, because only the best get the license to be a CPA. Most of them know their responsibilities and comply with auditing standards. This does not mean that we are in the right way; the paper recommends that there should be more attention, by auditors and institutions regulating the audit profession in Jordan, of the standards with the lowest degree compliance, especially standards concerning considering the work of internal auditing and auditor's responsibility to consider fraud in an audit of financial statements. Considerable steps should be taken to improve the ISA compliance in Jordan:

\section{Table 2: One-sample T test Result}

\begin{tabular}{lcc}
\hline Standard & Mean & T \\
ISA 200 & $82.76 \%$ & $* 30.000$ \\
ISA 210 & $85.52 \%$ & $* 43.646$ \\
ISA 220 & $80.69 \%$ & $* 29.718$ \\
ISA 230 & $87.59 \%$ & $* 34.843$ \\
ISA 240 & $73.79 \%$ & $* 34.843$ \\
ISA 250 & $87.59 \%$ & $* 26.504$ \\
ISA 260 & $78.62 \%$ & $* 28.760$ \\
ISA 300 & $87.59 \%$ & $* 26.017$ \\
ISA 315 & $81.38 \%$ & $* 42.001$ \\
ISA 320 & $87.59 \%$ & $* 34.849$ \\
ISA 330 & $82.76 \%$ & $* 25.610$ \\
ISA 402 & $76.55 \%$ & $* 47.834$ \\
ISA 500 & $90.34 \%$ & $* 29.113$ \\
ISA 501 & $81.38 \%$ & $* 23.112$ \\
ISA 505 & $87.59 \%$ & $* 34.255$ \\
ISA 510 & $85.52 \%$ & $* 30.463$ \\
ISA 520 & $76.55 \%$ & $* 30.463$ \\
ISA 530 & $80.00 \%$ & $* 30.509$ \\
ISA 540 & $80.00 \%$ & $* 22.139$ \\
ISA 545 & $82.07 \%$ & $* 26.737$ \\
ISA 550 & $80.69 \%$ & \\
ISA 560 & $82.76 \%$ &
\end{tabular}




\begin{tabular}{lll}
\hline ISA 570 & $84.14 \%$ & $* 26.311$ \\
ISA 580 & $89.66 \%$ & $* 42.020$ \\
ISA 600 & $70.34 \%$ & $* 21.746$ \\
ISA 610 & $74.48 \%$ & $* 20.895$ \\
ISA 620 & $77.24 \%$ & $* 28.000$ \\
ISA 700 & $86.90 \%$ & $* 34.946$ \\
ISA 701 & $75.86 \%$ & $* 22.657$ \\
ISA 710 & $82.07 \%$ & $* 24.548$ \\
ISA 720 & $76.55 \%$ & $* 27.151$ \\
ISA 800 & $75.17 \%$ & $* 23.201$ \\
Average & $81.62 \%$ & $* 56.899$ \\
\hline
\end{tabular}

* Significant at 0.05 level

Table 3: Ranking the Standards According to the Degree of Compliance

\begin{tabular}{llll}
\hline Rank & Standard & Rank & Standard \\
1 & IAS 500 & 17 & IAS 315 \\
2 & IAS 580 & 18 & IAS 501 \\
3 & IAS 230 & 19 & IAS 220 \\
4 & IAS 250 & 20 & IAS 550 \\
5 & IAS 300 & 21 & IAS 530 \\
6 & IAS 320 & 22 & IAS 540 \\
7 & IAS 505 & 23 & IAS 260 \\
8 & IAS 700 & 24 & IAS 620 \\
9 & IAS 210 & 25 & IAS 402 \\
10 & IAS 510 & 26 & IAS 520 \\
11 & IAS 570 & 27 & IAS 720 \\
12 & IAS 200 & 28 & IAS 701 \\
13 & IAS 330 & 29 & IAS 800 \\
14 & IAS 560 & 30 & IAS 610 \\
15 & IAS 545 & 31 & IAS 240 \\
16 & IAS 710 & 32 & IAS 600 \\
\hline
\end{tabular}

- ISA has not been widely available recently, and many audit practitioners have not had access to ISA-based practice manuals. So knowledge deficiencies constrain most Jordanian auditors in ensuring sound auditing practice.

- There should be translations to ISA which are not widely available; because local auditing firms that do not use English language suffer when translating and interpreting the standards.

- There should be more attention toward auditing standards under audit conclusions and reporting category and proper use of explanatory paragraphs in the audit reports. An audit firm may use an "emphasis of a matter" to deal with disagreement over accounting principles. Because auditors' report forms a gist of the audit procedure and many parties depend on it.
- Increased attention to auditor independence should be paid because it is the spirit of auditing, in addition to sharing useful information between auditors who precede and succeed each other with the same client. Because of severe competition, such communication almost never takes place.

- In spite of low cases of fraud in Jordan, the auditors should pay increased attention to auditor's responsibility to consider fraud in an audit of financial statements and apply appropriate procedures for discovering frauds and errors that may result in a material misstatement. We should not stay still until a disaster happens like big companies in the USA such as ENRON and WORLDCOM. Protective measures should be taken.

\section{REFERENCES}

1. World Bank, 2004. "Report on the Observance of Standards and Codes - Accounting and Auditing, (Jordan), the report is downloadable from World Bank website http://www.worldbank.org/ifa/rosc_aa_jor.pdf.

2. IFAC, 2007. "Handbook of International Auditing, Assurance, and Ethics Pronouncements", P: 7.

3. Horstmann, Charles A., 2005. "Playing a Leadership Role in International Convergence - A chance to set an example on the world stage", Journal of Accountancy, Vol. 200, Issue 4, P: 98.

4. $\mathrm{CCH}$ - Accountancy's publisher, 2006. "Auditors under pressure as ISAs start to bite", Accountancy Journal, Vol. 137, Issue 1351, PP: 18-19.

5. IFAC, 2004, "Study recommends convergence actions", Chartered Accountants Journal, Vol. 83, Issue 9, P: 65.

6. Abdullah, Khaled A., 2004. "Auditing Science Theoretical and Practical Aspect", Amman-Jordan, PP: 21-22. 